\title{
PRACTICAL ASPECTS OF REALIZATION OF THE DEVELOPMENT STRATEGY IN THE TOURISM REGION
}

\author{
Vera Rukomoinikova* \\ Volga State University of Technology, Yoshkar-Ola, Russia \\ Nadezhda Zykova \\ Volga State University of Technology, Yoshkar-Ola, Russia \\ Iraida Tumbaeva \\ Volga State University of Technology, Yoshkar-Ola, Russia
}

\begin{abstract}
Many authors have turned their research interests to the problem of efficiency of the tourism development strategy realization. It was the result of the fact that growth and implementation of the tourism development strategies appears to be the common world trend of the last decade. This research focuses on the territorial level. The paper concentrates on the small region of the central part of Russia through the example of which the authors want to retrace the realization of the tourism development strategy adopted by the municipal authorities. The major aim of the study has several objectives associated with the theoretical analysis of practical aspects of the tourism development prob-lem in the region. First of all, there is a need to provide a review of the literature devoted to the regional tourism efficiency evaluation. Secondly, it is necessary to measure the tourism efficiency in the region on the quantitative and qualitative level. The quantitative level re-fers to statistic data about the regional tourism. The qualitative level includes case study with self-employed individuals who set up their business in the field of rural tourism. Finally, this study has an overarching objective to identify the opportunities for the touristic potential of the small agricultural region of Mari El. It is quite currently important for the region to reveal the patterns according to which an inser-tion of private sector in the rural tourism development takes place. The research is based on international academic literature and the analysis of Russian experience.
\end{abstract}

Key words: Tourism development strategy, Long-term tourism development programs, Performance indicators, Cluster, Tourist destina-tion

\section{INTRODUCTION}

A strategic plan of management of the touristic sphere is important for the long term success in tourism development. Creation of successful strategic plan for tourism requires an application of the overall approach to the management of the region (tourism destination). The strategic plan should be developed on the base of analy-sis evaluation of the situation in the process of planning, including the review of service consumers' markets, operational surroundings, resources potential, existing products and environment. Strategic planning for the touristic sphere is a cyclical process which requires con-stant monitoring, reviewing and flexibility for adaptation to changing conditions.

The questions of the development of tourism strat- egies for countries and regions of the world as well as the questions of the domestic tourism level are considered on the official site of World Tourism Organization (UN-WTO). The site presents a short instruction of the devel-opment of tourism strategies. The objective of the stra-tegic program is defined as following: to define the foundation of the longterm development for tourism (10-20 years) with an accent on politics and strategies, planning, institutional consolidation of legislation and regulation, production development and its diversifica-tion, marketing and promotion, touristic infrastructure and overbuilding, economical impact of tourism on in-vestments in tourism, development of human resources and socio-cultural and ecological consequences of tourism.

The gradual plan of realization of tourism development strategies consists of three stages: de-

* Volga State University of Technology, Yoshkar-Ola, Russia (424000, Yoshkar-Ola, Lenin Square, 3; 
velopment of program scenario, detailed elaboration of master plan for every sector of touristic industry, realization of actions by means of technical assistance and financing (ration up to 150 thousand euro) from the side of WTO.

Strategic plans are elaborated not only for development of the tourism sphere of the country on the whole but in certain touristic directions such as: rural tourism, tourism of local communities, mountain tourism, coastal tour-ism, eco-tourism, spa tourism.

The theory and practice of development and implemen-tation of strategic programs of tourism development in the countries of the world are concentrated on the open resource Sustainable Tourism Online. The developer of this resource is Australia's Sustainable Tourism Cooperative Research Centre (STCRC). We will recite several important conclusions on the development of strategic plans and programs of tourism development presented by the Australian research centre. Development of stra-tegic touristic plan deals with the determination of stra-tegic priorities and directions which are revealed by con-cerned parties for planning, development management and marketing in the region. The STCRC researches consider the following to be the necessary conditions for tourism strategy realization: to identify specific respon-sibilities and time limits for realization of strategies and actions of concerned parties; to specify particular aims and measures for achievement of a strategic plan; to carry out regular monitoring and control over implementation of the strategy realization program; to develop tourism strategy as "alive" document which can be adapted and updated in case of operational surround-ings changes.

The next step of our research was the analysis of strate-gies and plans of development of tourism in the countries of Europe, America, Australia, Asia, Africa and Pacific Region. It is possible to come to some conclu-sions [14]. First, the absolute majority of documents was developed and implemented during the last decade. A small amount of countries that develop tourism on the governmental level has a long period of realization of program approach to the goals of the touristic sphere. It indicates that the sphere of tourism has started to take leading positions in national economies comparatively not long ago: at the turn of the century and till present.

Second, a number of analyzed strategies of tour- ism development can be distinguished by a detailed reasoned approach to realization of shaped plans, some programs have a declarative character. Nevertheless, practically all programs have a high level of governmental assistance.

Third, some countries realize development strategies not only on the national level but on the regional and munic-ipal levels as well. Moreover, the latter is noted for a high degree of details forethought.

Fourth, not all programs have a financial part that makes difficult their realization. Some strategies claim to achieve ambitious goals, but the indices of investments are either absent at all or not quite real.

On the whole, we can conclude that development and implementation of strategies of tourism development appears to be the common world trend of the last dec-ade.

\section{METHODOLOGY OF THE EFFICIENCY RE-SEARCH OF THE TOURISM STRATEGIES REALIZATION}

As for the methods of evaluation which form the basis of tourism efficiency, the following various methods are offered: the method of expert estimation based on the heuristic approach of Delphi [01], the method of hierarchy - Analytic Hierarchy Process [02], methods of grading - Superiority and Inferiority Ranking Method, the method of average weighted estimates - Weighted Sum Model [03], the method of additive optimization - Optimized Restricted Additive Methods [11]. In relation to the target audience various factors should be taken into account: tourists from different regions of the same country can be more demanding to the quality of certain factors which compose touristic attraction of the region. For example, it can be the quality of the road service or informational support of tourism [12]. In this case it is often necessary to revaluate significance of factors in-cluded into estimation of the potential [10].

Importance of the problem of tourist resources estimation is highlighted in the Federal Target Program "Development of domestic and incoming tourism in the Russian Federation in 2011 - 2016 years" [07]. Tourist potential of any area consists of natural and manmade objects and phenomena as well as of conditions, possibilities and means, necessary and suitable for the tourist product formation. Scientific conceptions 
of the tourist potential estimation offer a complex list of factors: natural and climatic resources ( weather conditions, landscape, water and mineral resources, flora, fauna, certain natural monuments and others), historical cultural resources (material and nonmaterial cultural heritage of the region) and socio economical resources (infrastructure of the touristic sector, managerial, human and educational, material, financial and informational resources and conditions). One can find interesting famous methods of estimation of tourist-recreational potential of territories that were elaborated by Aleksandrova A.Y., Drozdov A.V., Robinson B.V. and others. Ushakova E.O., Selivanov I.A. and others also suggest attractive patterns of complex estimation of tourist resources. An integrated evaluation model of tourist resources was proposed by Sarancha M.A. Results of tourist potential evaluation of the territory are presented in the tourist passport of the region. Federal Tourist Agency of the Russian Federation specifies requirements for the touris-tic passport of every region (territory) as regular and constantly renewing document. We will mention only some publications on evaluation of tourist potential by the example of certain regions: Khudenkhih Y.A. "Ap-proaches to evaluation of tourist potential of the territo-ry by example of regions of Perm kray", Karchevskaya E.N. "Methodological support of regional development and dimensional differentiation of tourism (by example of the Gomel region)", Kumova N.A. "Complex evalua-tion of tourist-recreational potential (by the example of the Kursk region)", Barsukova O.N. "Marketing evalua-tion of tourist potential (by the example of the tourist centre of Tobolsk)" and others.

As for evaluation of potential realization, researchers are mostly concentrated on economic methods of evaluation: increase of money receipts from tourism, raise of employment level, growth of income of local population and other economic results. Marketing and PR-factors also take part in evaluation of potential realization: increase of awareness about destination, growth of posi-tive feedbacks from tourists, degree of place's attraction, number of brand images in the consciousness of potential tourists. Critical effects of development of tourist potential are also taken into account, particularly, environmental impact: use of water, power consump-tion, release of wastes in the recreation area by guests. The following facts are compared, for example: tourist in Spain uses 880 liters of water per day against 250 liters used by locals [15].

An analysis of regional and municipal Russian tourist legislation demonstrates that the problem of estimation of efficiency of tourist potential realization is not less important on this level too, since there are no regional legislatives acts with clear instructions about methods of evaluation. Regional programs of tourism development as usual contain planned figures of program realization, such as: number of promotional and informational materials about tourist potential, number of Russian and international of specialized exhibitions, number of pro-motional and informational tours for Russian and for-eign mass media and tour operators, number of tourist informational terminals, number of tourists visiting the region, amount of touristic services, amount of invest-ments which were drawn as part of governmental financial support in the form of interests' refund of loans giv-en by commercial banks on the infrastructure develop-ment.

\section{APPLYING OF THE PROGRAM APPROACH IN THE STRATEGY OF TOURISM DEVELOPMENT IN RUSSIA}

In the last decade in Russia the questions of rise of strategic planning of the territory are discussed more frequently. Close attention is paid to the sphere of tourism: corresponding regulatory acts are being adopted, programs of development of tourist recreational centers are being created. In order to stimulate the development of different spheres governmental authorities realize a se-ries of actions which is mostly regulated by a legal act adopted at one or another level of governmental power (municipal, regional, federal). This approach can be called program-oriented or system and goal oriented, since legal acts that approve targeted programs consist of strictly defined set of appendices, where each appendix contain a series of actions, amount of financing of these actions and indices of actions efficiency. Every program specifies its objectives, results and actions efficiency indices. It should be noted that all regions in Rus-sia adopt such legal acts which sanction republican and regional targeted programs of development of domestic and incoming tourism.

In the process of investigation of tourism strategy development of the Russian Federation [5] we used the program approach which admits that in 
virtue of environment instability a targeted situation will again take in certain problems; the solution of these problems can't be found in advance. At the level of the territorial entities of the Russian Federation we developed a spatial model of cluster organization of tourism on the basis of determi-nation of territories having unique natural recreational and historical-cultural potential. These territories are considered as places for realization of cluster tourist ini-tiatives and formation of local tourist clusters. Govern-mental support of cluster initiatives is becoming a part of governmental strategy of increase of the Russian competitiveness in the sphere of tourism.

In the Strategy of tourism development in the Russian Federation till 2020 there is an interesting analysis of tourist potential of the regions of Russia according to federal districts. Today most territorial entities of the Russian Federation understand and admit significance of elaboration and implementation of programs of tour-ism development, however, the majority of projects is concentrated in Central, Northwestern and Volga dis-tricts as well as around famous tourist attractions in Siberia and Russian Far East.

The amount of financing of actions is included into the programs of Russian regions with account of finances from republican and federal budgets. In addition regions can rely on federal budget resources in case of insertion of tourist recreational projects and clusters in the federal targeted program of tourism development. Amounts of program financing by virtue of local budget resources usually have a forecasting character and are précised for every next year taking into account possibil-ities of budget of a particular region.

Efficiency of strategic programs of tourism development is manifested at the state level (creation of new working places, increase in taxes, attraction of investments) as well as at the regional level (decrease in social tension, solution of questions of ecological safety, improvement of infrastructure). Efficiency of activity of particular touristic businesses is estimated in marketing categories - volume and profitability of sales, advertising performance, business competitiveness, capital productivity, material productivity, coefficient of productive capacity use. Overall evaluation of efficiency of regional tourist potential use has to reveal the indices which characterize production structure of association, investment and in-nova- tive activity as well as economic indices: balance profit, sales proceeds, profitability. As can be seen from the above one of the important indicators of evaluation of strategic programs results in the sphere of tourism are the earning yield of the field.

\section{EFFICIENCY OF THE TOURISM DEVELOP- MENT PROGRAM BY THE EXAMPLE OF THE MARI EL REGION}

Through the example of the region of Mari El we will review realization of tourism strategy.

Mari El is a small in population size (687 435 people) region in the central part of Russia with a lower rate of urban population $(65,19 \%)$, the main types of settlements are rural and small towns.

According to researches the region has been in the state of modernization of the second type for a long time. It can be characterized by stagnation (growth without evolution); one of the reasons for this stagnation is imbalance of modernization parameters by reason of notice-able retardation of components of economical and cog-nitive indicators. The republic has not overcome the consequences of industrial failure in the 90th years of the XX century yet. The republic takes actions for diversifi-cation of economy, in particular, it is the adoption of the targeted program "Development of tourism in the repub-lic of Mari El for 2011-2016 years". At present the re-public possesses a quite high tourist potential, as well as intrinsic prerequisites for its development. Mari El is considered to be a region where authentic culture and traditions still exist; Mari people have saved till today Finno Ugric customs, traditions, religion and rites. It is the only nation in Europe which has the paganism as an official religion. In the republic there are several hundreds of Sacred groves, some of them are protected by the state. Natural recreational complex of the republic includes a big amount of small rivers and lakes, 2 nature reserves: "Bolshaya Kokshaga" and "Mari Chodra". All these factors give possibilities for development of cultural-cognitive, ecological and rural tourism.

In the republic there are 66 tour operators and travel agencies, the infrastructure includes 40 hotels and quest houses, 4 hostels, 30 health resorts, 9 tourist complexes and 18 recreational centers, 6 sports facilities, 20 sport clubs and fitness centers, 9 sports complexes and stadiums, 6 museums, 6 entertainment centers and 
complex-es, 3 cinema theatres. By estimate of the Committee on tourism of the republic of Mari $\mathrm{El}$ in 2014 domestic and incoming tourism flows (inclusive of sightseers) consti-tute 422,3 thousand people, foreign residents $-6,6$ thousand people, international tourism - 15 thousand people [6]. Herein after, we will show the statistics of tourist profitability for the last 5 years.

As can be noted from the above tables, number of tour-ist arrivals decreases while profitability indices increase due to the price advance and not to the number of arriv-ing people. The program of Mari El tourism for 6 years includes 215 million rubles of financial investments with account of governmental and private investments. The long term perspectives on the territory of the republic featuring private investors allows for creation and de-velopment of tourist-recreational clusters "Tsar-grad" in Yoshkar-Ola and "Volgydo" in Zvenigovsky and Gornomariysky regions and in Kozmodemiansk. The pro-jects listed above are included into the list of actions of the federal program "Development of domestic and incoming tourism in the Russian Federation", where the total amount of investments within the frame of clusters creation is more than 4 billion rubles. Nowadays on the territory of the republic a number of projects on devel-opment of domestic and incoming tourism and creation of necessary infrastructure are already realizing or planned to be realized in the nearest future. Among these projects we can mention formation of Mari tourist village "Vizimbir" in Kuzhenersky Region, eco-tourist complex "Chodyrayal" in Volzhsky Region, tourist complexes "Volgavita", "Okolitsa" and "Dvoryanskoe gnezdo" in Kilemarsky Region.
The authors of the paper believe that it is necessary to pay more attention to the development of rural tourism. Rural tourism includes all types of pastime of city dwellers in the countryside, i.e. elements of rest and health activities, ethnographic excursions.

At present development of this type of tourism is regard-ed as one of directions of innovative development of the agricultural center which enables to solve socio-cultural problems of rural population, to increase cultural and educational levels of rural population, stimulates preser-vation of local customs and folk crafts. The last decade of the $X X$ century saw an increasing interest to ecologi-cal and rural tourism [13]. Among the Volga regions Chuvash Republic and the Penza Region are extensively developing this tourist destination.

\section{RESULTS ANALYSIS OF CASE STUDY WITH ENTREPRENEURS OF THE RURAL TOUR- ISM IN MARI EL}

An empiric foundation includes statistics of qualitative underlying interviews with ten private entrepreneurs of 3 regions of Mari El. In the context of our research we conducted inquiries in 3 human settlements of Mari El: the villages of Maliy Kugunur (Orshansky Region), Aleshkino (Kilemarsky Region), Oshutyaly (Zvenigov-sky Region). The choice of human settlements in our research was determined by the fact that there were en-trepreneurs developing rural tourism. In the village of Maliy Kugunur there is a tourist complex country estate "Tihie zori", in Aleshkinotourist complex "Razdo-lie" in Oshutyal - tourist camp "Yushut".

Table 1: Income from tourism in Mari El, millions of rubles [08]

\begin{tabular}{|l|c|c||c||c||c||}
\hline \hline Tourism profitability indices in Mari El & 2009 year & 2010 year & 2011 year & 2012 year & 2013 year \\
\hline Amount of touristic services & 261 & 315 & 431 & 573 & 700 \\
\hline \hline Profitability turnover of hotels and restaurants & 1451 & 1662 & 2125 & 2252 & 2455 \\
\hline
\end{tabular}

Table 2: Dynamics of number of employees in the field of tourism and tourist arrivals in Mari El, thousands of people

\begin{tabular}{|l|c|c|c|c|c|}
\hline Statistic indices in the field of tourism in Mari El & 2009 year & 2010 year & 2011 year & 2012 year & 2013 year \\
\hline Number of travel agencies employees & 0,1 & 0,15 & 0,16 & 0,12 & 0,1 \\
\hline Number of hotels and restaurants employees & 2,8 & 2,7 & 3,6 & 3,9 & 3,6 \\
\hline $\begin{array}{l}\text { Number of Russian citizens housed incommunal } \\
\text { places of accommodation }\end{array}$ & 111,1 & 101,3 & 102,1 & 104,6 & 100,9 \\
\hline $\begin{array}{l}\text { Number of foreign citizens housed in communal } \\
\text { places of accommodation }\end{array}$ & 1,0 & 1,0 & 1,1 & 1,3 & 1,2 \\
\hline
\end{tabular}


All enterprises are considered as "small business", steadily work on the market of tourist services more than 3 years, actively present their services as rural tourism and can be named as typical examples in this sphere.

Non formalized interviews which were conducted with entrepreneurs and heads of enterprises made it possible to reveal some characteristics of their motivation and interaction with population. The entrepreneurs came to the sphere of rural tourism having significant experience in other fields of business and commercial structures. Their age is more than the average; one of the motives was a wish to "leave the hustle and bustle of the city", but at the same time to continue an active lifestyle and "to be helpful for people and society", "to maintain the movement for villages revival in Russia", "develop and maintain the national culture of the Mari nation". A social component in the motivation of entrepreneurs stipulates their positive attitude to the local society.

In the context of our research we defined two models of entrepreneurship in the country. The first model is con-sumer-oriented when an entrepreneur is focused on rural resources and doesn't have much impact on the local infrastructure. An entrepreneur has only economic influ-ence - assistance to the employment of local popula-tion. For example, owner of the country estate "Tihie zori", an entrepreneur, wasn't acquainted with traditions and culture of the local society. The reasons for the con-struction of the complex are beautiful and clean locality as well as availability of workforce from the nearby vil-lage.

The second model is called socio-cultural, when an en-trepreneur consciously specifies the task to encourage economical and socio-cultural development of the local community. It can be realized through traditional folk and ethno-cultural values: organization and carrying of festivals and holidays in the country. For example, the festival "Ancestral lands" is very popular in Kilemarsky Region. This festival was initiated by the director of the quest house "Razdolie". Later on, starting from the second year the festival was supported at the governmental level and became all republican.

Let's cite another example of social activity of an entre-preneur in the field of rural tourism. The director of the tourist camp "Yushut" set up his business with the aid of employment bureau in 2011. In the past during his Sovi-et childhood he attended the groups of tourism for chil-dren and young people. That's why while choosing an area for a tourist camp he initially thought about an appropriate place for rafting. Moreover, he is interested in development of youth movements. He became one of the organizers of the Forum of young entrepreneurs of Zvenigovsky Region within the frames of republican targeted program "Involvement of young people into the entrepreneurial activity in the Republic of Mari El in 20112015". He cordially hosted and accommodated all participants of the forum in his tourist camp in the vil-lage of Oshutyaly, Zvenigovsky Region. For one year and a half he managed to turn a deserted country estate in Oshutyaly into a stable enterprise specialized in coun-try-tourism. He actively shares his experience on the development of rural tourism in Zvenigovsky Region and considers it to be an advantageous course in the sphere of tourism. He belongs to the group of entrepre-neurs who intensively search for new dimensions in the traditional past of Mari and Tatar people.

\section{CONCLUSION}

Research results make it possible to talk about two dif-ferent groups of business activity in the rural Tourism of Mari El. The beginning of business activity of different individuals was developing differently. It is evident that there are two different motivations. The founder of the quest complex "Razdolie" came back to her home village in order to revive it. She has already had the initial capital. The founder of the holiday camp "Tihie zori" hasn't belonged to the local community before. He made his choice and decided to set up business in the untouched ecological canton of Russia.

In our research we called the two patterns of entrepreneur's interaction with local community as consumer oriented and pragmatic or sociallyoriented.

Positive results of business activity for resident population were noted by local respondents (in one case the road was repaired while in the other case the shop was opened). Activity of such enthusiasts is typical for the initial phase of the development of new directions. There is no doubt that rural tourism is a relatively new direction in the Russian tourism. However, according to the world experience enthusiasts' efforts are not enough to form a well-developed market of rural tourism services. It is possible to 
reach the maximum effect in the rural tour-ism development relying on the foreign experience (Ita-ly, Greece, Cyprus). There were two stages of the rural tourism in these countries: 1) start-up for account of rural entrepreneurs' activity; 2) results-oriented devel-opment by virtue of outside investments. At present de-velopment of the rural tourism in the republic of Mari El is on its first stage. For shifting to the second stage it is necessary to have governmental support in the form of development of goal-oriented programs and creation of favourable institutional environment.

\section{SUMMARY}

In our opinion in the rural tourism there are two patterns of value consciousness: the first deals with an individualistic structure of values; the second is a traditional one which is characterized with respect to traditions and ori-entation to family.

Research results of rural entrepreneur's economical be-haviour allow coming to the conclusion that a transition to economical growth in rural tourism is directly con-nected with the evolution of enterprises of consumer-oriented type to the market side and extension of their business activity. The government aim is to create fa-vourable institutional conditions for activity regulation of the strongest businesses, support of potentially active ones and protection of socially weak subjects of the rural entrepreneurship. In this situation it is possible to expect an economical and social effect from the entre-preneurial sector that can result into rural areas devel-opment in Russia.

\section{ACKNOWLEDGEMENTS}

The article was published with the financial support from Ministry of Education and Science of the Russian Federation within the framework of state assignment to the project № 26.1378.2014/ $K$ Socio-cultural resources of modernization in the efficiency evaluation of the territory development strategic programs in the context of domestic tourism.

\section{REFERENCES}

1) Cheng, F. 2008. Using the Delphi method to as-sess the potential of Taiwan's hot springs tourism sector. International Journal of Tourism Research, Vol. 10, Is-sue 4: 341-352.

2) Dwyer, L. \& Kim, C. 2003. Destination Compet-itiveness: Determinants and Indicators. Current Issues in Tourism, 6(5), 369-414.
3) Henderson, J. C. (2006). Tourism in Dubai: Overcoming Barriers to Destination Development. Inter-national journal of Tourism Research, 8, 87-89.

4) http://cooperation.unwto.org/technical-product/tourism-development-master-plans-andstra tegicdevelopment-plans (date accessed 10/10/2015).

5) http://government.ru/docs/12933/ (date accessed 10/10/2015).

6) http://mari-el.gov.ru/komtur/Pages/plans. aspx (date accessed 10/10/2015).

7) http://www.programs-gov.ru/razvitieturizma (date accessed 10/10/2015).

8) http://www.russiatourism.ru/content/8/ section/81/detail/4124/ (date accessed 10/10/2015).

9) http://www.sustainabletourismonline.com/ destinations-and-communities/destinationplanning/planning-process/strategic-plan (date accessed 10/10/2015).

10) latu, C. \& Bulai, M. (2011). New Approach in Evaluating Tourism Attractiveness in the Region of Moldavia (Romania). International Journal of Energy and Environment, 5, 165-174.

11) Mamun A. \& Mitra S. (2012). A Methodology for Assessing Tourism Potential: Case Study Murshida-bad District, West Bengal, India. International Journal of Scientific and Research Publications, Vol. 2, Issue 9, 6-18.

12) Mill, R.C. \& Morrison, A.M. (1999). The Tourism System. Dubuque, lowa: Kendall Hunt Publishing Company. 350.

13) Nikolayeva, A.N., Khalilova, T.V., Rukomoinikova, V.P. 2015. The Concept of the Regional Industrial Cluster Information Support. Mediterranean Journal of Social Sciences. MCSER Publishing, Rome-Italy. Vol 6, No 2: 29-35.

14) Polukhina, A.N., Rukomoinikova, V.P. 2015. Evaluation of the tourism development strategic pro-grams efficiency (by the example of the Volga Federal District). Monograph, Yoshkar-Ola. Volga State Univer-sity of Technology.

15) Romero, R. \& Homar V. 2012. Projections of the climate potential for tourism in Platja de Palma, Spain. International journal of Tourism Research, 11, 64-82.

Paper sent to revision: 31.01.2016.

Paper ready for publication: 22.02.2016.

Journal of Applied Engineering Science 14(2016)1, 355 
doi:10.5937/jaes14-10123

Broj rada: 14(2016)1, 355

\section{PRAKTIČNI ASPEKTI REALIZACIJE STRATEGIJE RAZVOJA U PODRUČJU TURIZMA}

\section{Rukomoinikova V.P., Državni Univerzitet Tehnologije u Volgi, Mari El, Rusija \\ Zykova N.N., Državni Univerzitet Tehnologije u Volgi, Mari El, Rusija \\ Tumbaeva I.D., Državni Univerzitet Tehnologije u Volgi, Mari El, Rusija}

Mnogi autori su okrenuli istraživačke interese ka problemu efikasnosti realizacije strategije razvoja turizma. To je rezultat činjenice da se pojavljuje rast i sprovođenje razvoja strategije turizma da bude zajednički svetski trend u poslednjoj deceniji. Ovo istraživanje se fokusira na teritorijalnom nivou. $U$ radu se koncentriše na malom prostoru centralnog dela Rusije na primeru koji su autori želeli da dožive realizaciju strategije razvoja turizma usvojenog od strane opštinskih vlasti. Glavni cilj ovog istraživanja ima nekoliko ciljeva u vezi sa teorijskom analizom praktičnih aspekata razvoja turizma problema u regionu. Pre svega, postoji potreba da se obezbedi pregled literature posvećene regionalnoj evaluaciji efikasnosti turizma. Drugo, neophodno je meriti turističku efikasnost u regionu na kvantitativnom i kvalitativnom nivou. $U$ kvantitativnom nivou odnosno statističkim podacima o regionalnom turiz-mu. Kvalitativna nivo obuhvata studiju slučaja sa pojedincima samozaposlene koji su osnovali svoj posao u ob-lasti seoskog turizma. Na kraju, ova studija ima glavni cilj da identifikuje mogućnosti za turistički potencijal malih poljoprivrednih regiona Mari El. Sasvim je trenutno važno za region da otkrije uzorke prema kojem je Insercija privatnog sektora u razvoju seoskog turizma odvija. Istraživanje je bazirano na međunarodnoj akademskoj literaturi i analizi ruskog iskustva.

Ključne reči: Strategija razvoja turizma, Programi dugoročnog razvoja turizma, Indikatori učinka, Klaster, Turistička destinacija 